Background: Long-term administration of macrolide antibiotics is recognized to be able to favorably modify the clinical condition of inflammatory diseases, such as diffuse panbronchiolitis and cystic fibrosis. However, the precise mechanisms by which macrolide antibiotics could improve clinical conditions of the patients are not well understood.

Aim: The present study was designed to examine the influence of macrolide antibiotics on effector cell functions responsible for inflammation through the choice of roxithromycin (RXM) and mast cell.

Methods: Mast cells were induced by long-term culture of splenocytes from BALB/c mice. RXM was added to the cultures at seeding and then every 4-5 days, when the culture medium was replaced with a fresh one. The influence of RXM on mast cell growth was evaluated by counting the number of cells grown on the 16th day. We also examined the influence of RXM on mast cell activation by examining histamine release and inflammatory cytokine secretion.

Results and conclusion: RXM could not inhibit mast cell growth, even when splenocytes were exposed to $100 \mu \mathrm{g} / \mathrm{ml}$ of RXM throughout the entire culture periods. RXM also could not suppress histamine release from cultured mast cells in response to nonimmunological and immunological stimulations. However, RXM could suppress inflammatory cytokine, interleukin-1 $\beta$, interleukin-6, granulocyte macrophage-colony stimulating factor and tumor necrosis factor- $\alpha$, secretions induced by concanavalin $A$ stimulation at a concentration of as little as $0.5 \mu \mathrm{g} / \mathrm{ml}$. These results may suggest that RXM modulated the ability of mast cells to secrete inflammatory cytokines and results in improvement of clinical condition of chronic inflammatory diseases.

Key words: Roxithromycin, Mast cell growth, In vitro, Mouse splenocytes, Inflammatory cytokines, IL-1 $\beta$, IL-6, TNF- $\alpha$, GM-CSF, Inhibition

\section{Influence of a macrolide antibiotic, roxithromycin, on mast cell growth and activation in vitro}

\author{
Toshikazu Shimane ${ }^{1}$, Kazuhito Asano ${ }^{2, c A}$, \\ Mayumi Suzuki ${ }^{1}$, Tadashi Hisamitsu ${ }^{2}$ and \\ Harumi Suzaki ${ }^{1}$
}

\begin{abstract}
${ }^{1}$ Department of Otolaryngology and ${ }^{2}$ Department of Physiology, School of Medicine, Showa University, 1-5-8 Hatanodai, Shinagawa-ku, Tokyo 142-8555, Japan
\end{abstract}

\author{
${ }^{\mathrm{CA}}$ Corresponding author \\ Tel: +81337848110 \\ Fax: +81337845368 \\ E-mail: asanok@med.showa-u.ac.jp
}

\section{Introduction}

Sinobronchial syndrome involves the coexistence of chronic rhinosinusitis and chronic lower airway inflammation such as chronic bronchitis and diffuse panbronchiolitis. Although these diseases are well recognized to be resistant against several types of treatment, we use macrolide antibiotics, and satisfactory results are obtained when the patients are given the agents in one-half the recommended therapeutic doses for more than 3 months. ${ }^{1}$ The efficacy of this macrolide therapy on the inflammatory diseases is generally believed to be due to their anti-inflammatory effects, ${ }^{2,3}$ but the precise mechanisms are not well defined.

Histopathological observations have revealed the accumulation and activation of inflammatory cells, eosinophils and neutrophils in local inflammatory reactions. There is an established concept that these inflammatory cells produce several types of chemical mediators (e.g. histamine and serotonin) that are harmful to tissue and responsible for the modification of inflammatory responses. ${ }^{4,5}$ Inflammatory cytokines such as interleukin (IL)-1 $\beta$, IL- 4 , IL- 6 and tumor necrosis factor- $\alpha$ (TNF- $\alpha$ ) are also generally believed to function in the regulation of inflammatory responses as one of the final effector molecules. ${ }^{6,7} \mathrm{~A}$ lot of reports clearly showed that roxithromycin (RXM), a macrolide antibiotic, strongly inhibits inflammatory cytokine production from $T$ cells and macrophages in vitro and in vivo. ${ }^{8,9}$ It is also reported that erythromycin (EM) caused a reduction in neutrophil functions such as chemotaxis and free oxygen radical production. ${ }^{10,11}$ These reports may suggest that the inhibitory action of 
macrolide antibiotics on both inflammatory cytokine production and inflammatory cell functions constitutes a possible mechanism of action that could explain the beneficial effects of the agents on inflammatory diseases.

Tissue mast cells and circulating basophils are well known to be one of the effector cells in inflammatory responses through their immunoglobulin E (IgE)dependent release of chemical mediators. It is also reported that mast cells can secrete inflammatory cytokines such as IL-4, IL- 6 and TNF- $\alpha$ in response to immunological and non-immunological stimulations, and contribute to the development of inflammatory diseases. ${ }^{12-14}$ However, the effect of macrolide antibiotics on mast cell functions are poorly understood. In the present study, therefore, we examined the influence of macrolide antibiotics on mast cell functions using RXM and in vitro cell culture technique.

\section{Materials and methods}

\section{Mice}

BALB/c male mice, 7 weeks of age, were purchased from Charles River Japan Inc. (Atsugi, Japan).

\section{Conditioned medium}

Conditioned medium of WEHI-3 cells containing IL-3 was obtained by the culture of $2 \times 10^{5}$ cells $/ \mathrm{ml}$ of WEHI- 3 cells (donated from Riken Cell Bank, Tsukuba, Japan) at $37^{\circ} \mathrm{C}$ in a humidified atmosphere with $5 \%$ $\mathrm{CO}_{2}$ in air for $72 \mathrm{~h}$ in RPMI-1640 medium (Flow Laboratories, North Ride, Australia) supplemented with $10 \%$ fetal calf serum (Flow Lab), $5 \times 10^{-5} \mathrm{M} 2 \mathrm{ME}$, $20 \mathrm{mM}$ HEPES, $100 \mathrm{U} / \mathrm{ml}$ of penicillin and $100 \mu \mathrm{g} / \mathrm{ml}$ of streptomycin (RPMI).

\section{Drugs}

RXM was kindly supplied by Aventis Pharm Co., Ltd. (Tokyo, Japan) as a water-insoluble pure powder. The agent was dissolved in methyl alcohol at $20.0 \mathrm{mg} / \mathrm{ml}$ and diluted with RPMI, so as to give a concentration of $1.0 \mathrm{mg} / \mathrm{ml}$. This solution was then filtered through a $0.22-\mu \mathrm{m}$ filter (Nihon Millipore Corp., Yonezawa, Japan) and stored at $4^{\circ} \mathrm{C}$ as a stock solution. All dilutions used in this study were prepared from this stock solution by diluting with RPMI containing 50\% conditioned medium (Complete Medium). Murine recombinant interferon- $\gamma($ IFN- $\gamma)\left(\right.$ specific activity, $\left.1.9 \times 10^{6} \mathrm{U} / \mathrm{ml}\right)$ was kindly provided by Tray Industries, Inc. (Kanagawa, Japan), and used as a mast cell growth inhibitor. $^{15}$

\section{Cell preparation and cell culture}

Spleen cell suspension was prepared as described previously. ${ }^{8}$ The cells were adjusted to $10 \times 10^{6}$ cells/ $\mathrm{ml}$ in Complete Medium. The cells $(1.0 \mathrm{ml})$ were incubated in 24-well cluster plates (NUNC, Inc., Naperville, IL, USA) at $37^{\circ} \mathrm{C}$ in a humidified atmosphere with $5 \% \mathrm{CO}_{2}$ in the presence or absence of the agents in a total volume of $2.0 \mathrm{ml}$. One-half of the culture medium was changed every 4-5 days.

\section{Treatment of cells with agents}

RXM was added to the cells at seeding and then every 4-5 days, when the culture medium was replaced with fresh medium. To study the effect of RXM at different stages of the cells, another series of experiments was carried out, in which addition of RXM to the cultures at seeding and 10 days after seeding were compared. INF- $\gamma$ was also added to the cultures in a similar manner.

\section{Cell counts}

The growth of the cells was measured by counting cells in a hemocytometer. Cell viability was checked by trypan blue dye exclusion. Mast cells were counting according to the methods described by Gilbert and Ornstain. ${ }^{16}$ Each result is expressed as the mean value \pm SE of six determinations in triplicate cultures.

\section{Mast cell separation}

Cultured mast cells were separated from dead cells and small lymphocytes by Histopaque-1077 (Sigma Chemicals, St. Louis, MO, USA) density gradient centrifugation. Cultured cells were collected on day 16 and washed three times with serum-free RPMI. The cells were re-suspended in the fresh medium, layered on Histopaque-1077 and centrifuged at 1500 r.p.m. for $10 \mathrm{~min}$ at $25^{\circ} \mathrm{C}$. Separated cells were then collected and re-suspended in Complete Medium. More than 98\% of separated cells were stained following the method of Gilbert and Ornstain. ${ }^{16}$

\section{Histamine release from cultured mast cells}

Cultured mast cells were suspended in Hank's balanced salt solution (HBSS) at a concentration of $5 \times$ $10^{5}$ cells in the presence or absence of various concentrations of RXM. The cells were then stimulated with either $10.0 \mu \mathrm{g} / \mathrm{ml}$ of compound $48 / 80$ or $1.0 \mu \mathrm{g} / \mathrm{ml}$ of calcium ionophore $\mathrm{A} 23187$ at $37^{\circ} \mathrm{C}$ for $30 \mathrm{~min}$. The reaction was terminated by chilling the tubes in an ice bath. ${ }^{17}$ After centrifugation at 
3000 r.p.m. for $10 \mathrm{~min}$ at $4^{\circ} \mathrm{C}$, the supernatants were collected. The pelleted cells were then re-suspended in HBSS and sonically disrupted to extract residual histamine. Histamine contents were measured by commercially available histamine enzyme-linked immunosorbent assay (ELISA) test kits (IBL GmbH, Hamburg, Germany) according to the manufacturer's recommended procedure. The results were expressed as the mean percentage inhibition of histamine release \pm SE of five determinations. In examining the influence of RXM on immunologic release of histamine, cultured mast cells were suspended in HBSS that contained various concentrations of RXM. The cells were sensitized with $10.0 \mu \mathrm{g} / \mathrm{ml}$ of mouse $\mathrm{IgE}$ (Yamasa Co. Ltd., Chiba, Japan) for $60 \mathrm{~min}$ at $37^{\circ} \mathrm{C}$, and washed three times with HBSS containing various concentrations of RXM. The sensitized cells were then treated with anti-mouse IgE monoclonal antibody (Nordic Immunological Lab., Tilburg, The Netherlands) at $37^{\circ} \mathrm{C}$ for $30 \mathrm{~min} .{ }^{17}$ The subsequent procedures were the same as those carried out after addition of compound $48 / 80$ or calcium ionophore A23187.

\section{Production of cytokines from cultured mast cells}

Separated mast cells $\left(2 \times 10^{6}\right.$ cells $\left./ \mathrm{ml}\right)$ were placed in triplicate in 24-well cluster plates (NUNC) that contained various concentrations of the agents and $2.5 \mu \mathrm{g} / \mathrm{ml}$ of concanavalin A (Con A) (Sigma Chemicals) in a final volume of $2.0 \mathrm{ml}$. The plates were maintained at $37^{\circ} \mathrm{C}$ in a humidified atmosphere of $5 \%$ $\mathrm{CO}_{2}$ in air for $24 \mathrm{~h}$. Culture supernatants were obtained after pelleting cells by centrifugation at 3000 r.p.m. for $10 \mathrm{~min}$ at $4^{\circ} \mathrm{C}$, and stored at $-40^{\circ} \mathrm{C}$ until use.

\section{Measurement of cytokines}

IL-1 $\beta$, IL-6, TNF- $\alpha$, and granulocyte macrophagecolony stimulating factor activities in culture supernatants were assayed using the commercially available mouse cytokine ELISA Test Kits (Genzyme/Techne Corp., Cambridge, MA, USA). The ELISA was carried out in duplicate according to the manufacturer's protocol. The sensitivity of each ELISA kit is IL- $1 \beta<$ $10 \mathrm{pg} / \mathrm{ml}$, IL- $6<15 \mathrm{pg} / \mathrm{ml}$, TNF- $\alpha<10 \mathrm{pg} / \mathrm{ml}$, and granulocyte macrophage-colony stimulating factor < $5 \mathrm{pg} / \mathrm{ml}$.

\section{Statistical analysis}

Statistical differences between the two groups were evaluated by analysis of variance combined with Fisher's PLSD test.

\section{Results}

\section{Influence of RXM on mast cell growth in vitro}

The first set of experiments was designed to examine the influence of RXM on mast cell growth from mouse splenocytes in vitro. We first examined the kinetics of mast cells growth from mouse splenocytes. As shown in Fig. 1, the number of mast cells gradually increased, peaked on the 16th day and declined thereafter. We next examined the influence of RXM on mast cell growth. To do this, 10.0 or $100.0 \mu \mathrm{g} / \mathrm{ml}$ of RXM were added to the cells at seeding and then every 4-5 days, when the culture medium was replaced with a fresh one. The mast cell numbers were counted on day 16. RXM could not inhibit mast cell growth from splenocytes even when splenocytes were exposed throughout the entire culture period to RXM: the number of mast cells observed in cultures containing $100.0 \mu \mathrm{g} / \mathrm{ml}$ of RXM was quite similar (not significant, $p>0.05$ ) to that in control cultures (Fig. 2A). On the contrary, IFN- $\gamma$ (a mast cell growth inhibitor) showed a suppressive effect on mast cells growth when splenocytes were exposed to IFN- $\gamma$ at more than $100 \mathrm{U} / \mathrm{ml}$ (Fig. 2B).

We next examined the effects of RXM at different stages of mast cell growth. To accomplish this, 10.0 and $100.0 \mu \mathrm{g} / \mathrm{ml}$ of RXM was added to the cultures 10 days after seeding, and the mast cell numbers were counted on the 16th day. The data in Fig. 3A show that RXM could not suppress mast cell growth even when $100.0 \mu \mathrm{g} / \mathrm{ml}$ of RXM was added to the cultures. This negative suppression of mast cells growth was also observed in cultures that received IFN- $\gamma$ on day 10 (Fig. 3B).

\section{Influence of RXM on histamine release from cultured mast cells}

The second sets of experiments was carried out to examine the influence of RXM on histamine release from cultured mast cells. As shown in Fig. 4A, RXM could not inhibit histamine release from mast cells in response to chemical substance (compound 48/80 and calcium ionophore A23187) stimulations. This negative inhibitory action of RXM was also observed when the cells were stimulated immunologically using mouse IgE and anti-mouse IgE (Fig. 4A). The data in Fig. 4B show that IFN- $\gamma$ could not inhibit histamine release from mast cells as in the case of RXM.

\section{Influence of RXM on cytokine secretion from cultured mast cells}

The third experiments were designed to examine whether RXM could inhibit cytokine secretion from 


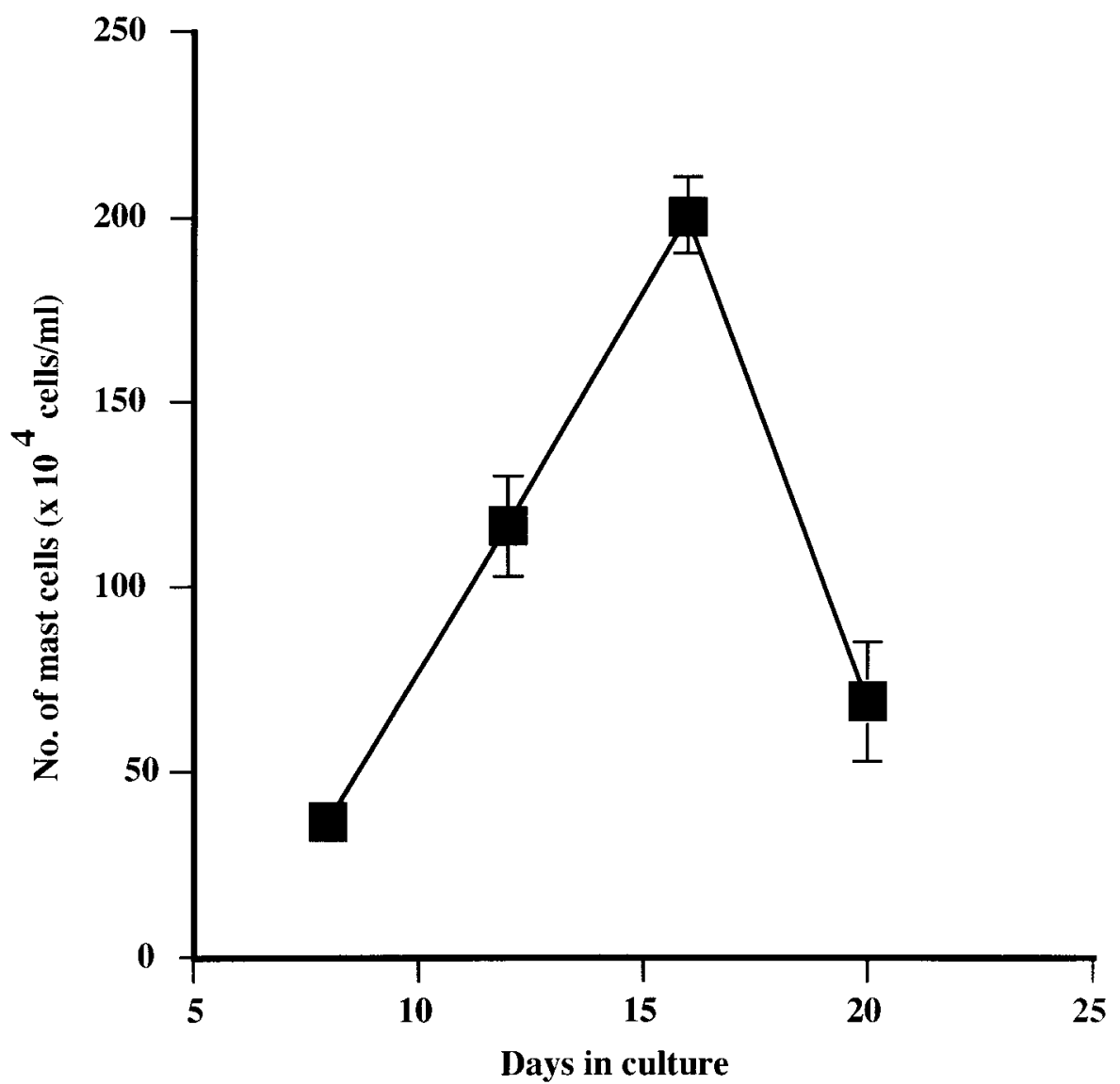

FIG. 1. Mast cell induction in cultured murine splenocytes. Spleen cells $\left(1 \times 10^{7}\right.$ cells $\left./ \mathrm{ml}\right)$ were cultured, and the culture medium was replaced with the fresh one every $4-5$ days. Mast cells were counted when the culture medium was replaced. Each point represents the mean \pm SE from six determinations in triplicate cultures.

cultured mast cells in response to mitogenic stimulation. As shown in Fig. 5, RXM caused a reduction in cytokine secretion. This suppression was observed when the cells were stimulated with Con A in the presence of RXM at a concentration of as little as $0.5 \mu \mathrm{g} / \mathrm{ml}$.

\section{Discussion}

Long-term administration (for more than 3 months) of macrolide antibiotics is reported to favorably modify the clinical status of inflammatory disorders such as diffuse panbronchiolitis, asthma and chronic rhinosinusitis. ${ }^{1}$ Furthermore, this macrolide therapy is used for the treatment of cystic fibrosis, which is the most common autosomal recessive disorder in Caucasians, and it has been reported that there was a significant improvement in lung functions following treatment. ${ }^{18,19}$ Although these reports may suggest that macrolide therapy is recognized as one available treatment for chronic inflammatory diseases, the precise mechanisms by which macrolide antibiotics could improve clinical conditions of the patients are not well defined.
It is well known that there are several distinct inflammatory pathways, each of which proceeds via a cascade of biological events. ${ }^{20}$ Many of the individual steps in the inflammatory cascade are controlled by soluble factors such as histamine and serotonin that are secreted mainly from mast cells and eosinophils, so-called final effector cells. ${ }^{20}$ Yet the action of RXM on these effector cell functions is not well understood. To examine the influence of RXM on effector cell functions we chose mast cells, and first tested cell growth using an in vitro cell culture technique. The present results clearly show that RXM could not suppress mast cell growth from normal mouse splenocytes. Furthermore, this negative inhibitory effect of RXM on mast cell growth is also observed when the agent was added to cultures on day 10. Mast cells are reported to be derived from precursors that originated in the bone marrow and then reside in blood, peripheral mucosa and peripheral tissues including spleen and lymph nodes. ${ }^{21}$ It is also recognized that inflammatory responses in these sites bring about differentiation and proliferation of precursors and matured mast cells, and result in accumulation of numerous mast cells. ${ }^{21}$ Together with these reports, the present results clearly show that RXM, 


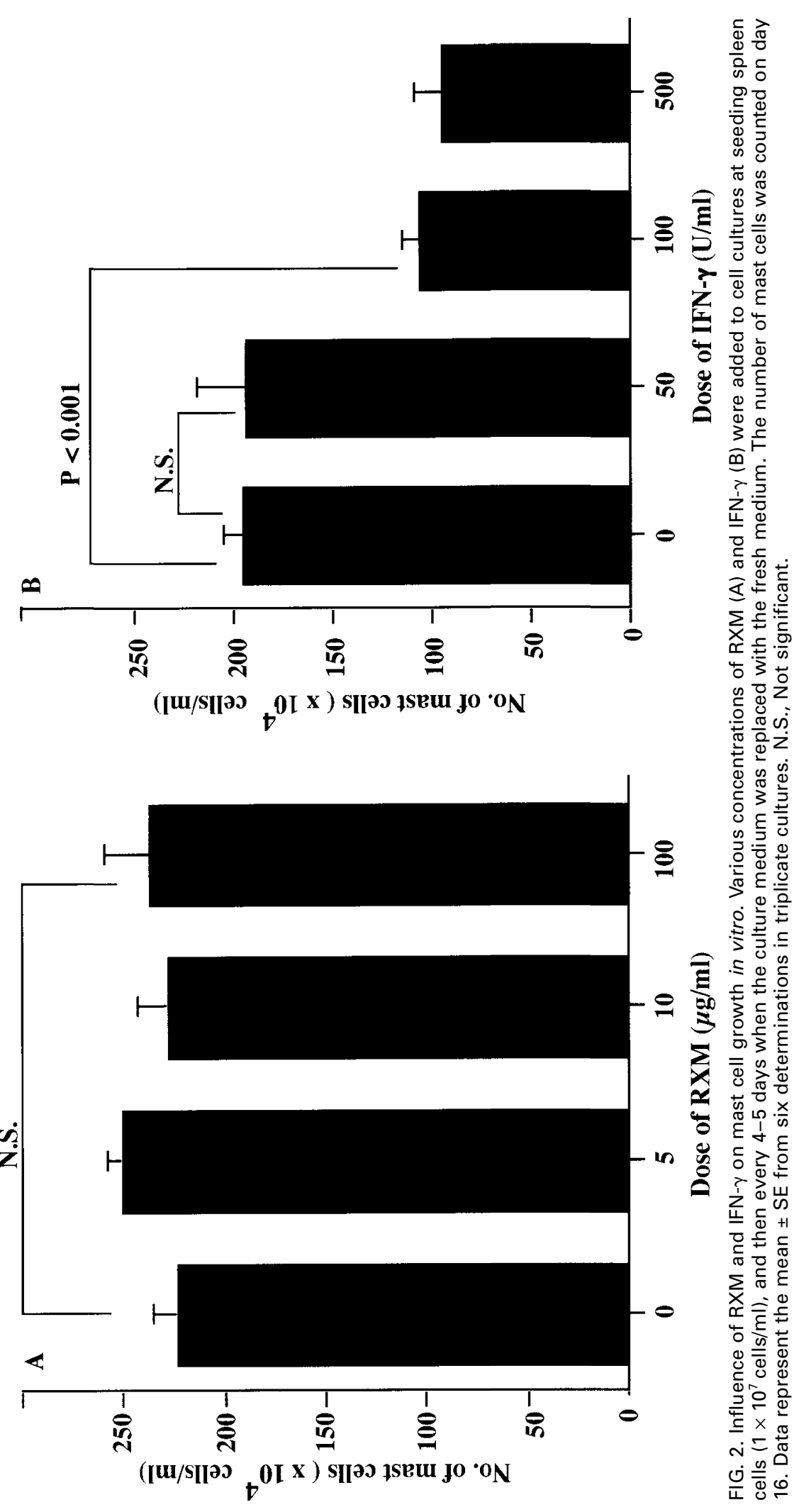



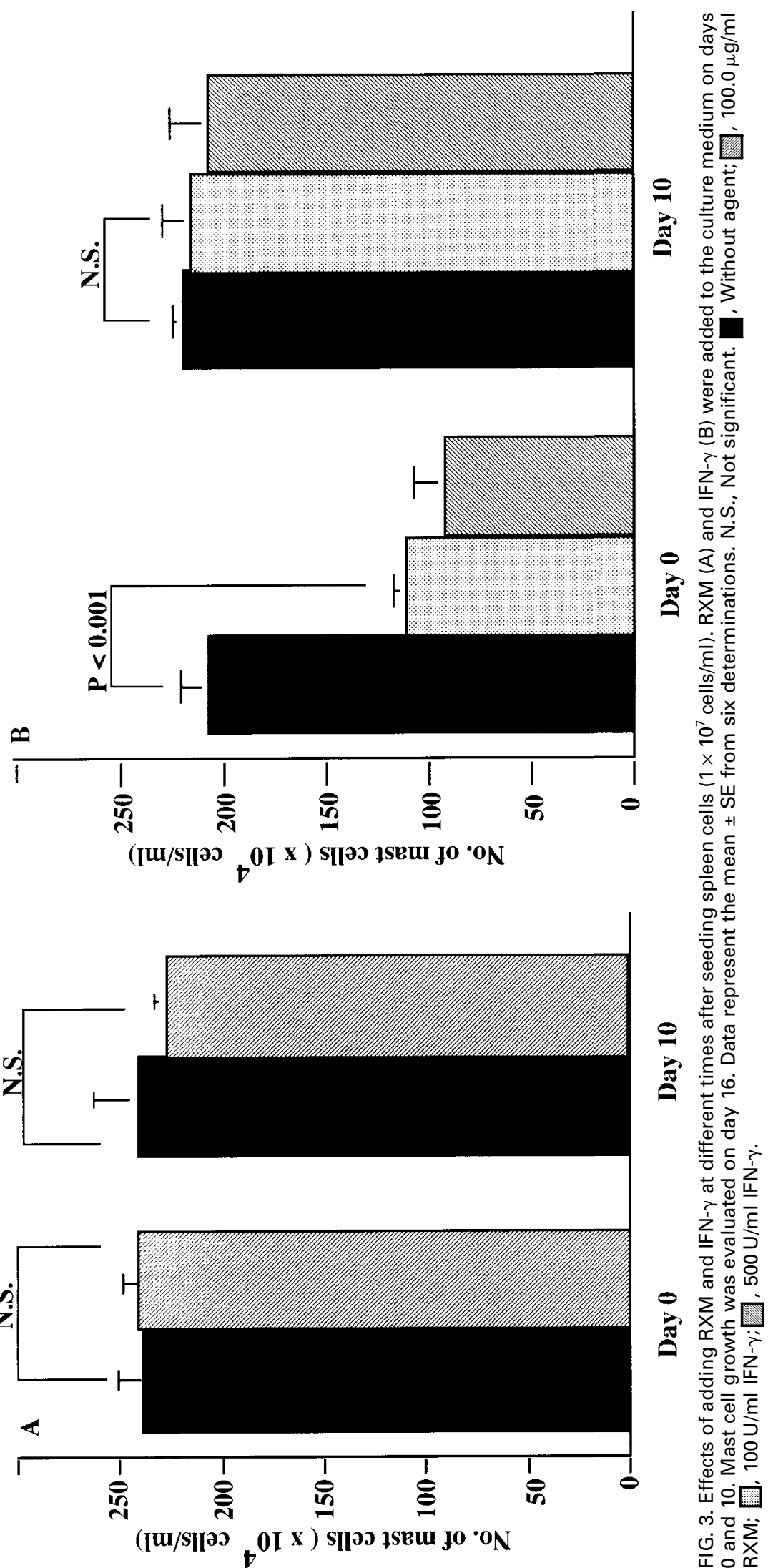


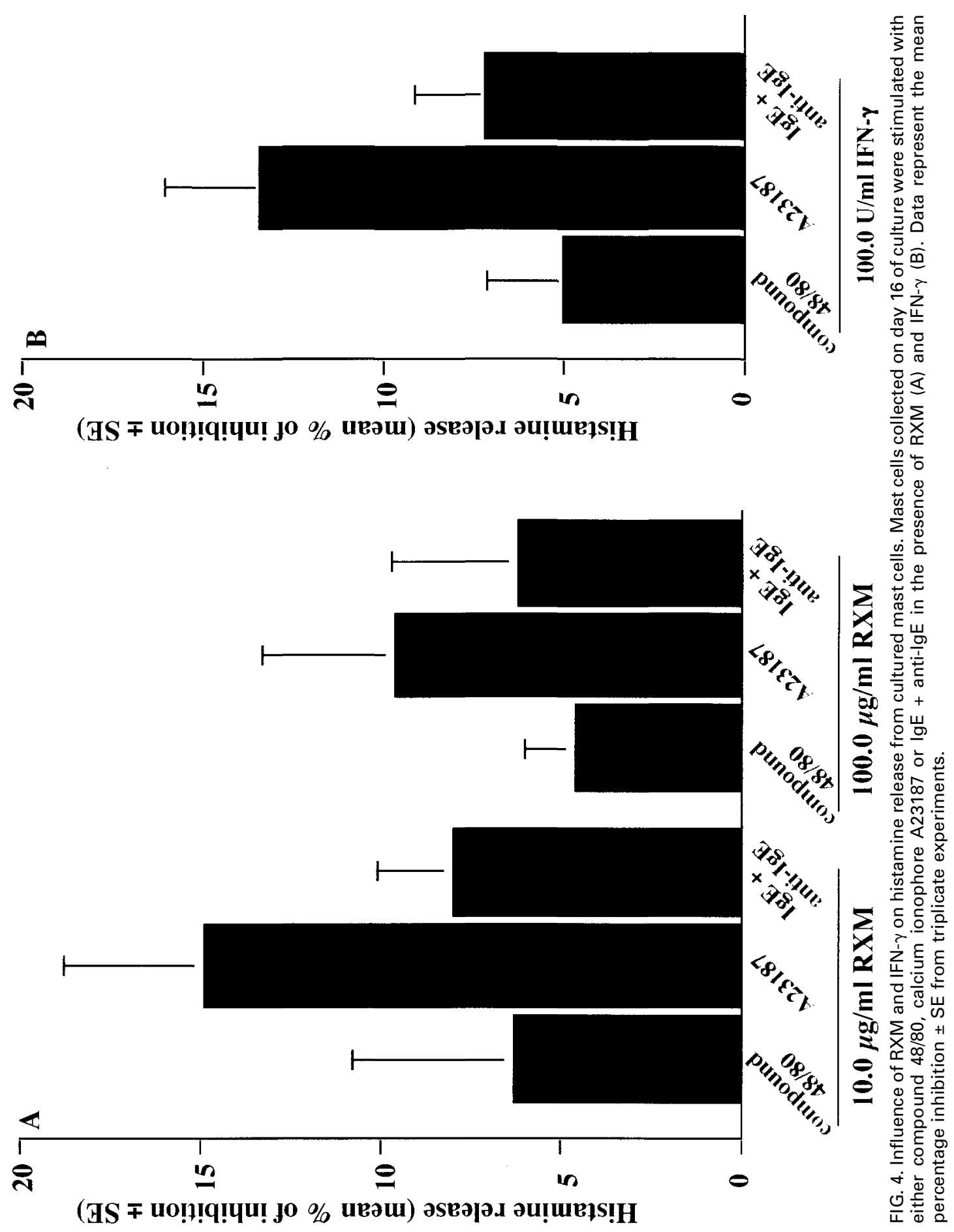




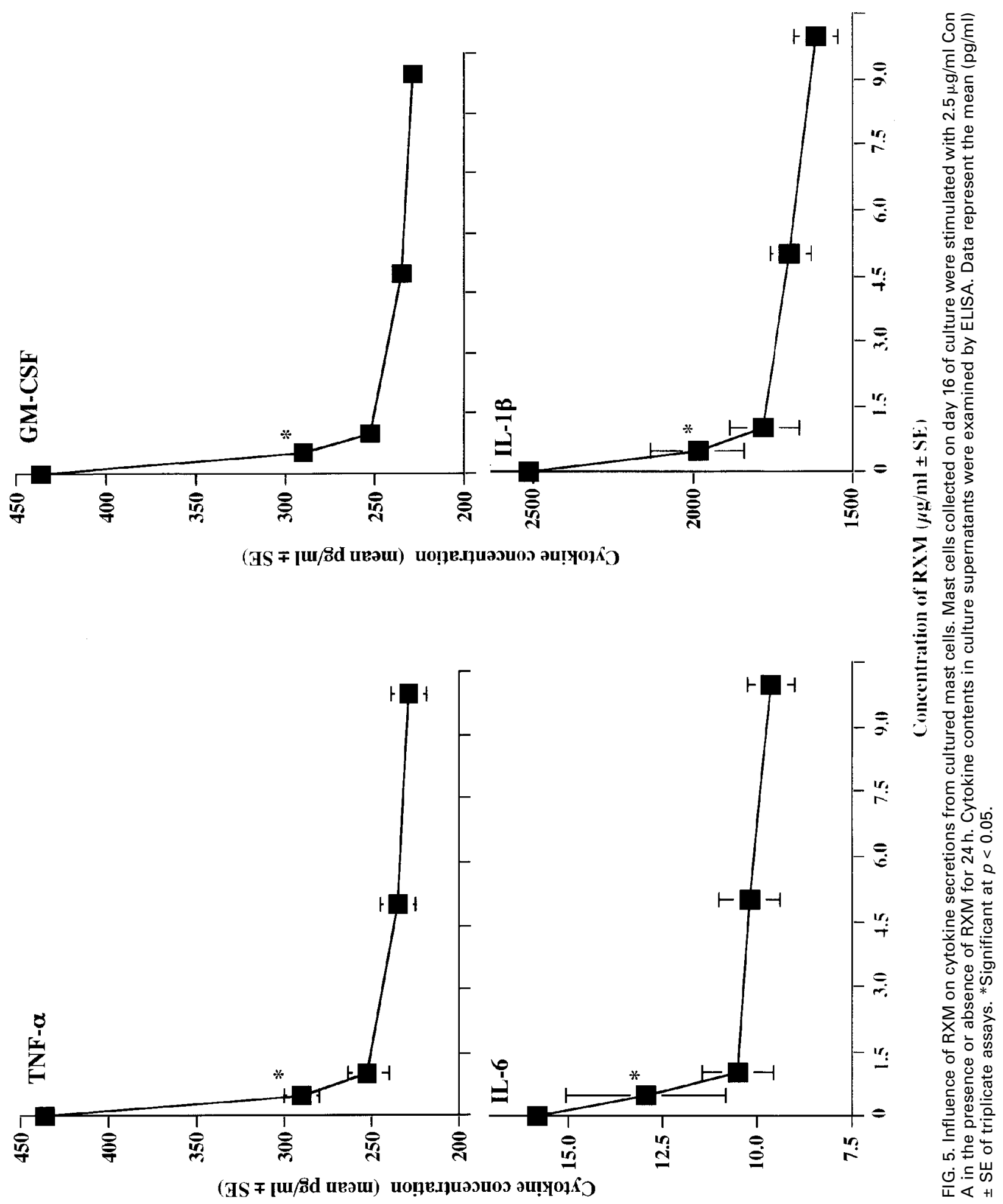


different from IFN- $\gamma$, does not exert harmful effects on mast cell precursors and mature mast cells. It is also reasonable to speculate that the present results may be interpreted that RXM does not interfere with differentiation and proliferation of mast cells even when the agent is administered into patients with chronic inflammatory diseases for a long period (more than 3 months).

We next examined the influence of RXM on mediator release from cultured mast cells. As shown in Fig. 4, RXM could not inhibit histamine release even when the cells were stimulated in the presence of $100 \mu \mathrm{g} / \mathrm{ml}$ of RXM. EM prevents calcium influx into cells, ${ }^{22}$ resulting in reduced permeability of the cell membrane and inhibition of histamine release from mast cells in response to non-immunological and immunological stimulations. It is also observed that EM increases the content of intracellular cyclic adenosine monophosphate (cAMP), ${ }^{23}$ which elaborates an important downregulatory signal in the release of mediators synthesized in cytosol. $^{24,25}$ From these reports, it is possible that RXM prevents accumulation of calcium cation in the cytosol and enhances the intracellular cAMP level, resulting in inhibition of histamine secretion.

Inflammatory cells, including mast cells, are reported to secrete not only chemical mediators, but also several types of inflammatory cytokines, and to control the development of inflammatory responses. ${ }^{26}$ Therefore, we finally examined whether RXM could suppress inflammatory cytokine production from mast cells. As shown in Fig. 5, RXM exerts suppressive effects on inflammatory cytokine production from mast cells in response to Con A stimulation in vitro. It is reported that EM and RXM inhibit inflammatory cytokine production from $T$ cells and macrophages through the inhibition of mRNA expression. ${ }^{27}$ EM has also been reported to suppress IL-8 mRNA expression and activation of both nuclear factor- $\mathrm{KB}$ and activator protein-1 in bronchial epithelial cells. ${ }^{28,29}$ Taken together, the present results may be interpreted such that RXM inhibits both inflammatory cytokine mRNA expression and activation of transcription factors, and results in inhibition of inflammatory cytokine productions.

Given the importance of cytokines in the pathogenesis of inflammatory disorders ${ }^{4}$ and the observation that mast cells are an important source of several inflammatory cytokines, ${ }^{12-14}$ the present results may suggest that treatments which target cytokine secretion from mast cells may be useful in the control of inflammatory diseases. This suggestion may be supported by the observation that corticosteriods and FK-506, which have no ability to interfere with chemical mediator release from mast cells, could favorably modify the clinical status of diseases by inhibition of inflammatory cytokine secretion from mast cells in vivo. ${ }^{30,31}$ Furthermore, the present results suggest the possibility that some of the therapeutic effects of RXM on inflammatory diseases depends on their ability to reduce the secretion of inflammatory cytokines from mast cells as well as mononuclear leukocytes such as $\mathrm{T}$ cells and macrophages.

\section{References}

1. Iino Y, Toriyama M, Kudo K, et al. Erythromycin inhibition of lipopoly saccharide-stimulated tumor necrosis factor alpha production by human monocytes in vitro. Ann Otol Rbinol Laryngol 1992; 101 (Suppl 157) $16-20$.

2. Miyatake H, Taki F, Taniguchi H, et al. Erthyromycin reduces the severity of bronchial hyperresponsiveness in asthma. Chest 1991; 99: 670-673.

3. Miyatake H, Suzuki K, Taki F, Takagi K, Satake T. Effect of erythromycin on bronchial hyperresponsiveness in patients with bronchial asthma. Arzneimittelforschng 1991; 41: 552-556.

4. Nadel JA. Inflammation and asthma. J Allergy Clin Immunol 1984; 73 651-653

5. Holtzman MJ, Fabbri LM, O'Byrne PM, et al. Importance of airway inflammation for hyperresponsiveness induced by ozone. Am Rev Respir Dis 1983; 127: 686-690.

6. Hosford D. Paubert-Braquet M. Braquet P. PAF/cytokine interactions in regulation of the inflammatory response. In: Sorg $\mathrm{C}$, ed. Cytokines regulating the allergic responses. Basel: Karger, 1989: 51-72.

7. Lett-Brown MA, Alam R, Grant JA. Regulation of basophil and mast cell activation by cytokines In: Sorg $\mathrm{C}$, ed. Cytokines regulating the allergic responses. Basel: Karger, 1989: 90-99.

8. Konno S, Asano K, Kurokawa M, et al. Antiasthmatic activity of a macrolide antibiotic, roxithromycin: analysis of possible mechanisms in vitro and in vivo. Int Arch Allergy Immunol 1994; 105 308-316.

9. Suzaki H, Asano K, Ohki S, et al. Suppressive activity of a macrolide antibiotic, roxithromycin, on pro-inflammatory cytokine production in vitro and in vivo. Med Inflamm 1999; 8: 199-204

10. Miyachi Y, Yoshida A, Imamura S, Niwa Y. Effects of antibiotics on generation of reactive oxygen species. J Invest Dermatol 1986; 86 449-453

11. Eyrand A, Descotes J, Lombard JY, et al. Effects of erythromycin josamycin and spiramycin on rat polymorphonuclear leukocyte chemotaxis. Chemotheraphy 1986; 32: 379-382.

12. Gordon JR, Galli SJ. Mast cells as a source of both performed and immunological inducible TNF- $\alpha$ /cachetin. Nature 1990; 346: 274-276.

13. Kinet JP. The high-affinity receptor for IgE. Curr Opin Immunol 1989; 2: 499-505.

14. Bradding P. Human mast cell cytokines. Clin Exp Allergy 1996; 26 13-19.

15. Konno S, Adachi M, Asano K, et al. Inhibitory effect of interferon-beta on mouse spleen-derived mast cells. Med Inflamm 1993; 2: 243-246.

16. Gilbert HS, Ornstain L. Basophil counting with a new staining method using alcian blue. Blood 1975; 46: 279-286.

17. Ennis M, Truneh A, White JR, Pearce FL. Inhibition of histamine secretion from mast cells. Nature 1981; 289: 186-187.

18. Jaffe A, Francis J, Rosenthal M, Bush A. Long-term azithromycin may improve lung function in children with cystic fibrosis. Lancet 1998; 351 420.

19. Altschuler EL. Azithromycin, the multidrug-resistant protein, and cystic fibrosis. Lancet 1998; 351: 1286

20. Kay AB. Role of T cells in asthma. Allergy Int 1997; 46: 73-82.

21. Ashman RI, Jarboe DL, Conrad DH, Huff TF. The mast cell-committed progenitor. In vitro generation of committed progenitors from bone marrow. J Immunol 1991; 146: 211-216.

22. Zhao DM, Xue HH, Chida K, et al. Effect of erythromycin on ATP-induced intracellular calcium response in A5 49 cells. Am J Physiol Lung Cell Mol Physiol 2000; 278: 724-736.

23. Depoortere I, Peeters TL. Transduction mechanism of motilin and motilides in rabbit duodenal smooth muscle. Regulat Pept 1995; 55 227-235.

24. Endres S, Fulle HJ, Sinha B, et al. Cyclic nucleotides differentially regulate the synthesis of tumor necrosis factor- $\alpha$ and interleukin- $1 \beta$ by human mononuclear cell. Immunology 1991; 72: 56-60.

25. Shimozato T, Iwata M, Kawada H, Tamura N. Human immunoglobulin preparation for intravenous use induces elevation of cellular cyclic adenosine $3^{\prime} 5^{\prime}$-monophosphate levels, resulting in suppression of tumor necrosis factor alpha and interleukin 1 production. Immunology 1991; 72: $497-501$

26. Kay AB. Asthma and inflammation. J Allergy Clin Immunol 1991; 87: 893-910. 
27. Konno S, Gonokami Y, Kurokawa M, et al. Inhibitory action of roxithromycin on cytokine production in vitro. Jpn J Antibiotics 1995; 48 (Suppl A): 105-107.

28. Takizawa $\mathrm{H}$, Desaki $\mathrm{M}$, Ohtoshi $\mathrm{T}$, et al. Erythromycin modulates IL-8 expression in normal and inflamed human bronchial epithelial cells. Am J Respir Crit Care Med 1997; 156: 266-271.

29. Desaki M, Takizawa H, Ohtoshi T, et al. Erythromycin suppresses nuclae factor- $\mathrm{\kappa} \mathrm{B}$ and activator protein-1 activation in human bronchial epithrial cells. Biochem Biophys Res Commun 2000; 267: 124-128.

30. Hatfield SM, Roehm NW. Cyclosporine and FK506 inhibition on murine mast cell cytokine production. J Pharmacol Exp Ther 1992; 260: 680-688

31. Wershil BK, Furuta GT, Lavigne JA, et al. Dexamethasone and cyclosporin A suppress mast cell-leukocyte cytokine cascades. I Immunol 1995; 154: 1391-1398.

\section{Received 9 August 2001}

Accepted 7 September 2001 


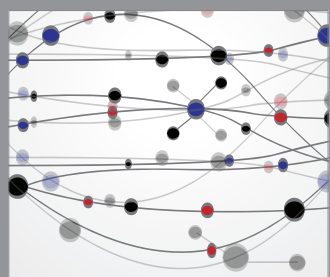

The Scientific World Journal
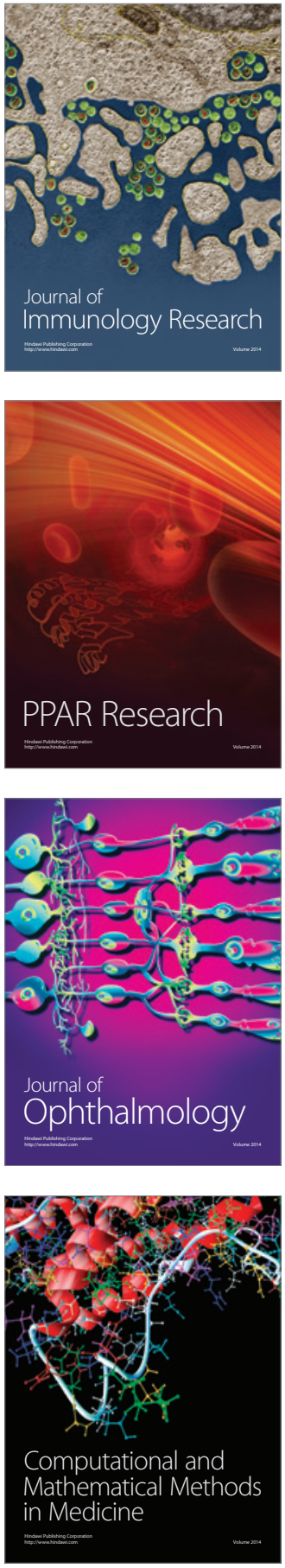

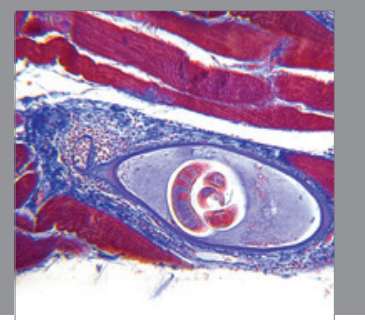

Gastroenterology

Research and Practice
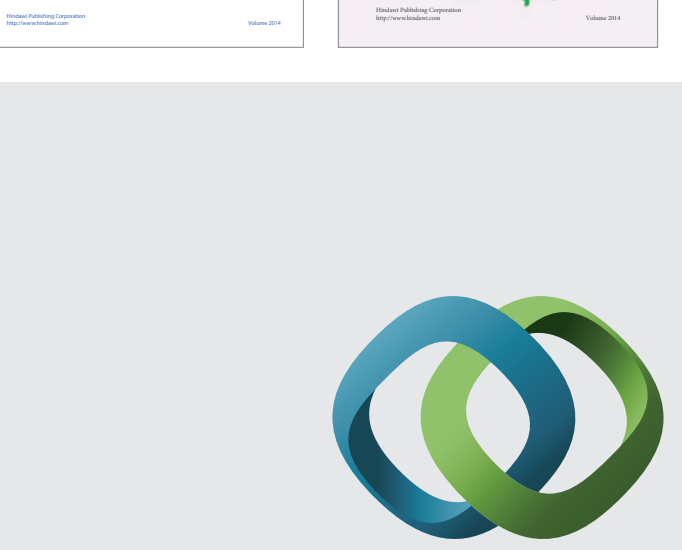

\section{Hindawi}

Submit your manuscripts at

http://www.hindawi.com
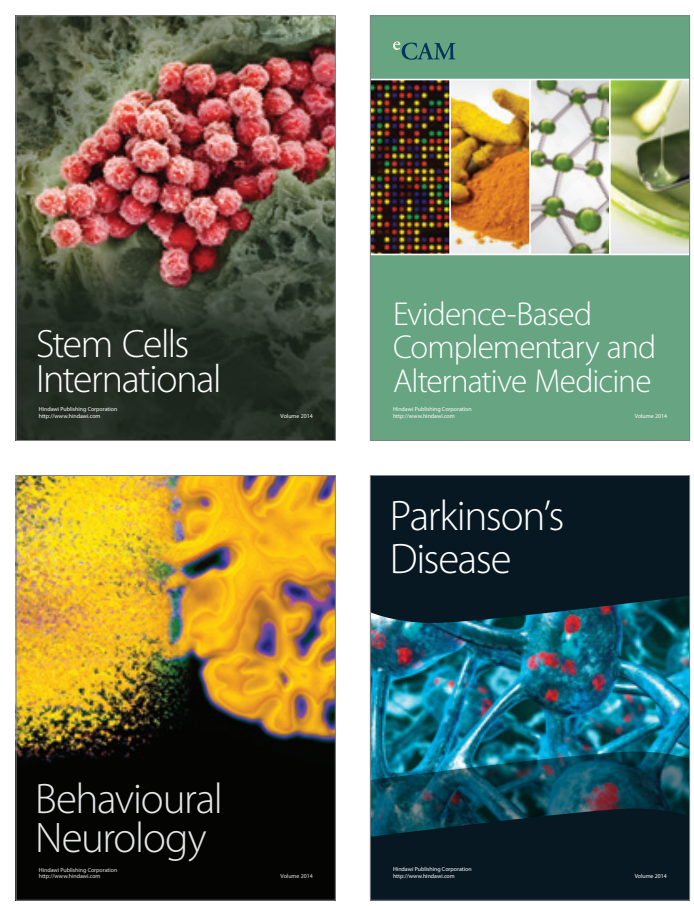

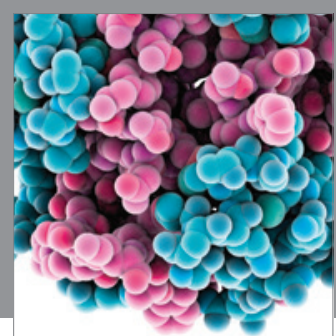

Journal of
Diabetes Research

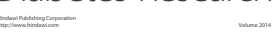

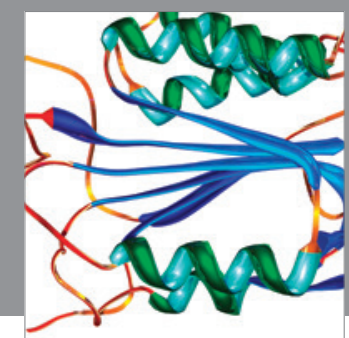

Disease Markers
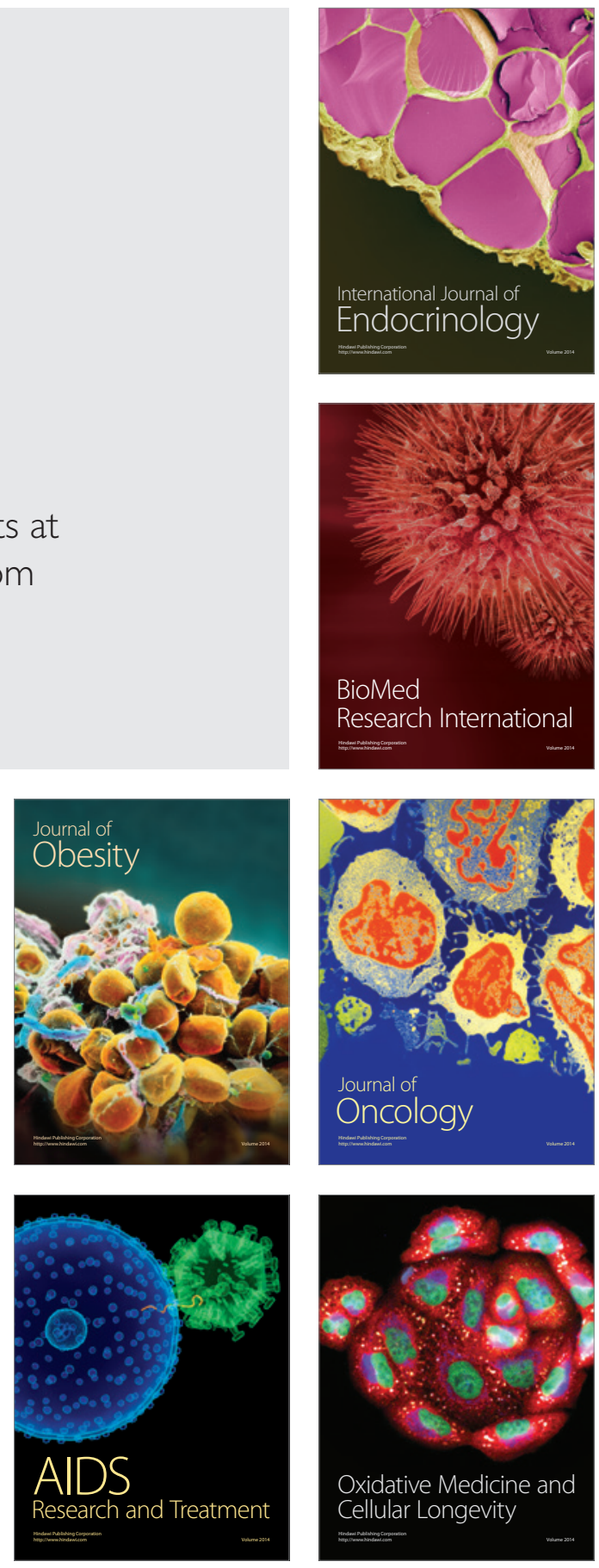